\title{
Comparative Study on Performance of Tasar Silkworm, Antheraea mylitta, Drury under Chawki Garden and Direct Rearing Method
}

\author{
S. Kamaraj*, T. Pandiaraj, Immaual Gilwax Prabhu, \\ Nidhi Vishwakarma and A.K. Sinha
}

\author{
Scientist, Central Tasar Research and Training Institute, Ranchi, Jharkhand-835 303, India \\ *Corresponding author
}

\begin{tabular}{|c|c|}
\hline & B S T R A C T \\
\hline $\begin{array}{l}\text { Chawki, } \\
\text { Cocoon, Mortality, } \\
\text { Silkworm tasar }\end{array}$ & \multirow{3}{*}{$\begin{array}{l}\text { A comparative experiment study was carried out with chawki and direct brushing tasar } \\
\text { silkworm on the tasar silkworm's host plant Arjun leaves. The chawki method was carried } \\
\text { out during I and II instars larva followed succeeding instars brushed in common plot } \\
\text { whereas, direct brushing method was reared entire life cycles in common block plantation } \\
\text { plots. The results indicated duration of silkworm larva was observed four days earlier with } \\
\text { reared in chawki method than direct brushing method. Mortality rate of silkworm was } \\
\text { found minimum under Chawki method. Tasar silkworm reared under chawki method had } \\
\text { higher larval weight as compared to direct brushing method. Similarly, maximum cocoon } \\
\text { weight, shell weight and shell ratio was obtained in chawki rearing practices. Hence, the } \\
\text { results of present study clearly designate the tasar silkworm rearing with chawki garden } \\
\text { during initial stage improves the rearing performance and cocoon characters of tasar } \\
\text { silkworm. }\end{array}$} \\
\hline Article Info & \\
\hline $\begin{array}{l}\text { Accepted: } \\
20 \text { March } 2017 \\
\text { Available Online: } \\
10 \text { April } 2017\end{array}$ & \\
\hline
\end{tabular}

\section{Introduction}

The Tasar silkworm, Antheraea mylitta Drury (Daba TV) is a commercial and wild sericigenous insect, exists in nearly 17 Indian states in the form of 44 ecological populations (ecoraces) or biotypes (Mohanty, 2003). The tasar silkworm, Antheraea mylitta Drury is a trivoltine (three crops/year) polyphagous insect feeding on a host of food plants but primarily feeding on Terminalia Arjuna, Terminalia tomentosa and Shorea robusta. The traditional rearing of Antheraea mylitta D., tasar silkworm on forest grown trees resulted in $80-90 \%$ crop loss due to pests, predators, natural calamities and diseases (Hari and Seth, 1999). The majority of crop loss in tasar silkworm rearing is resulting due to pest such as ants and birds during young stage larval period called chawki stage (I and II instars stage). Moreover, as the rearing is conducted completely outdoors in the forest, there is no control over the climatic conditions (rain, temperature and humidity) and thereby the rearing of tasar silkworms are subjected to many fluctuations in the climatic conditions that often lead to viral attacks (Singh et al., 1992).

Chawki rearing is one of the vital activities in tasar silkworm rearing, which enables the farmers to reap good harvest of quality cocoons. Young age silkworm rearing comprises of rearing of $1^{\text {st }}$ and $2^{\text {nd }}$ instar larvae under most care with nutritious and easily digestible feed. In traditional method of 
tasar silkworm rearing, young larvae is directly released on host plants without care of chawki garden. Farmers are used to brush silkworms on host plants through leaf cups and this method results in frequent silk yield losses. Thus, chawki rearing method is essential for ensuring success and stability of silkworm crops. Most of the tasar sericulture farmers lack the above facilities to do chawki rearing on their own. The advantages of chawki rearing methods are rising of robust young silkworms, stabilization of crop and increase of cocoon yield, control over disease occurrence and spread, reduction in expenditure, distribution of labour for other farm works and facilitation of batch brushing and efficient crop supervision. In this context, a comparative study was taken up to find out the performance of tasar silkworm in direct and chawki rearing methods.

\section{Materials and Methods}

An experiment was conducted during $1^{\text {st }}$ rearing crop (Kharif) season of 2015 at Pilot Project Centre, Hatgamharia, West Singhbhum district of Jharkhand which is situated at $22^{\circ} 26^{\prime} \mathrm{N}$ Latitude and at $85^{\circ} 74^{\prime} \mathrm{E}$ Longitude at an altitude of 260 meters above MSL. The region enjoys a humid to subtropical climate and receives a mean annual rainfall of $1160 \mathrm{~mm}$ in 100 rainy days. Of this, nearly about 85 per cent is received during south - west monsoon $\left(2^{\text {nd }}\right.$ week of June $-1^{\text {st }}$ week of October). Average maximum and minimum temperature during the growing season were 30.6 and $23.5^{\circ} \mathrm{C}$, respectively.

The disease free laying (Dfl), eggs were collected from PPC, Hatgamharia. Dfls were washed properly by $5 \%$ Depurotex then dried under eggs dryer machine for 20 mins. Chawki garden was established with Arjun plantations. Seventy plants were established with $120 \mathrm{~cm} \mathrm{X} 120 \mathrm{~cm}$ spacing and used as chawki garden. Periodically Arjun plants were pollarded with $90 \mathrm{~cm}$ height. Chawki bushes were hygienically maintained by destroying weeds, and unhealthy braches. Lime and bleaching powder mixture has been sprinkled in and around the field at the ratio of 9:1 to prevent the attacks of pest and diseases.

Before the start of young age rearing, the plants of chawki garden are covered by nylon net with size of $12 \mathrm{~m} \mathrm{X} \mathrm{9m} \mathrm{X} \mathrm{3m} \mathrm{along} \mathrm{with}$ support of bamboo poles. One such net could covers 70 plants and with rearing capacity of 225 dfls during chawki period. After second instar those larvae shifted to separate block plantation for late age rearing. In another hand, traditional practices of direct tasar silkworm rearing methods were followed as per the standard procedure. All agronomical practices were followed as per recommended package of practices in the field during rearing period.

\section{Results and Discussion}

\section{Rearing performance}

Data presented on table 1 show that larval duration varied from initial instar and there is no significant variation was observed in last instars. In our experiment, the rearing was started with one Dfl each on same period in direct and chawki method of silkworm rearing. Although duration of instars observed invariably, date of spinning was consistently differed in chawki method as compared to direct method of tasar silkworm rearing. Chawki rearing method silkworm observed that spinning of tasar silkworm larvae had been completed in four days earlier (17-082015) than direct method (19-08-2016). So, larval duration of chawki rearing method was 30 days whereas direct method of silkworm rearing performance was 34 days to complete life cycle. This might be due to enriched leaf 
was available in chawki garden and special care has taken to maintain the chawki garden trees. Similar result was also corroborated by Sekar (1995). In direct method of silkworm rearing was observed more losses of silkworms due to pest, disease and other climatic factors than chawki method. In this study, worm losses with direct method were observed 135 numbers as compared to 83 numbers in chawki method. Hence, higher number of harvestable tasar silkworm cocoons had obtained in chawki method (86) than direct method (38). Similarly effective rate of rearing (ERR) percentage was also higher under chawki method and it was $10.7 \%$ higher than direct method of silkworm rearing practices.

\section{Mortality rate}

The mortality by parasites, pests and predators and rainfall of tasar silkworm, Antheraea mylitta, Drury during the rearing period are presented in table 2. During the rearing period, losses in direct rearing due to virosis, bacteriosis, mycosis, pebrine, pest, predators, malnourishment and others were 9,
$5,1,2,80,20$ and 49, respectively (total loss 166) while that in the chawki rearing were 1 , $0,1,1,1,1,1,22$, respectively (total loss 37 ). These data on pest and disease incidence in the present investigation that loss due to bacterial, viral and pest and predators and other factors in direct method rearing much higher than that in chawki rearing method. Owing to loss of worms in direct method conditions due to climatic and pests there was four times higher depletion losses than chawki garden method. This might be due to larvae grown during initial stage in chawki method fed nutritive and hygienic leaves led to developed more immune system and successfully sustained against vagaries biotic and abiotic stress condition in later stage of larval development period. Mahobia and Yadav (2010) in order to identify specific reasons for low productivity of Antheraea mylitta, Tasar silkworm rearing, conducted a survey on Daba ecorace at Bastar Plateau of Chhattisgarh during 2003-04, based on the data indicated that the $15.01 \%$ of bacterial incidence followed by $12.08 \%$ of virosis, $10.58 \%$ of Pebrine and the other accounted for $7.07 \%$ at larval, moth and cocoon levels.

Table.1 Rearing performance of tasar silkworms on direct rearing method in host plants under block plantation and chawki methods

\begin{tabular}{|l|l|l|}
\hline \multicolumn{1}{|c|}{ Parameters } & Direct method & Chawki method \\
\hline $1^{\text {st }}$ Instar (duration) & 4 days & 3 days \\
\hline $2^{\text {nd }}$ Instar (duration) & 4 days & 3 days \\
\hline $3^{\text {rd }}$ Instar (duration) & 5 days & 4 days \\
\hline $4^{\text {th }}$ Instar (duration) & 8 days & 7 days \\
\hline $5^{\text {th }}$ Instar (duration) & 13 days & 13 days \\
\hline Date of spinning & $21-08-2015$ & $17-08-2015$ \\
\hline Total larval period & 34 days & 30 days \\
\hline $\begin{array}{l}\text { Date of harvesting } \\
\text { harvestable cocoons }\end{array}$ & $39-08.2015$ & $25-08.2015$ \\
\hline $\begin{array}{l}\text { Worms loss due to } \\
\text { diseases/pest and } \\
\text { predator }\end{array}$ & 38.08 .2015 & 86.2015 \\
\hline ERR $\%$ & 135 & 83 \\
\hline
\end{tabular}


Table.2 Mortality rate of tasar silkworms due to various pest and disease on direct rearing method in host plants under block plantation and chawki methods

\begin{tabular}{|l|c|c|}
\hline \multicolumn{1}{|c|}{ Parameters } & Direct method & Chawki method \\
\hline Virosis & 9 & 1 \\
\hline Bacteriosis & 5 & 0 \\
\hline Mycosis & 1 & 1 \\
\hline Pebrine & 2 & 1 \\
\hline Pest and predators & 80 & 11 \\
\hline Malnourishment & 20 & 1 \\
\hline Others & 49 & 22 \\
\hline \multicolumn{1}{|c|}{ Total } & $\mathbf{1 6 6}$ & $\mathbf{3 7}$ \\
\hline
\end{tabular}

Fig.1 Larva weight of tasar silkworm on direct rearing method in host plants under block plantation and chawki rearing methods

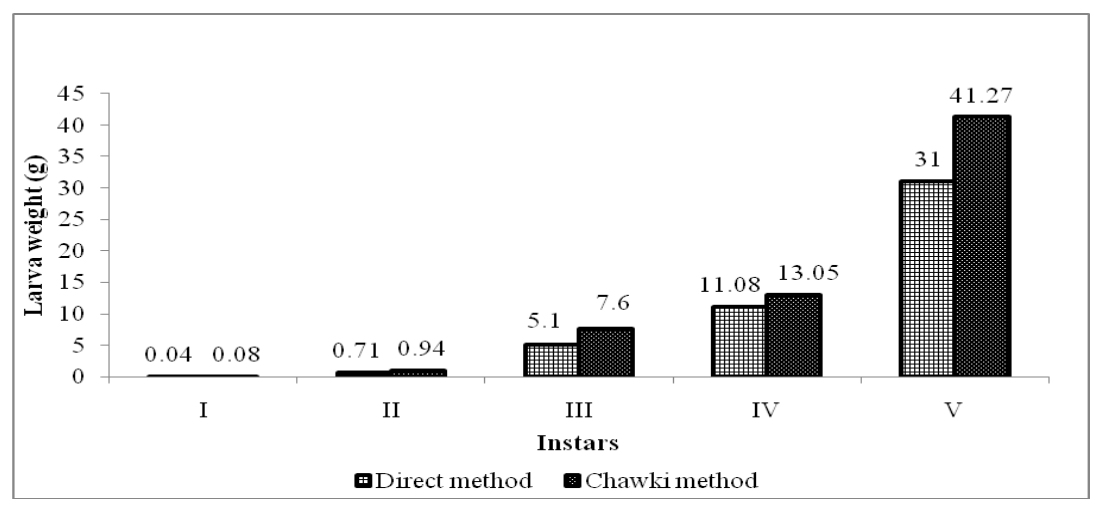

Fig.2 Cocoon characters of tasar silkworm on direct rearing method in host plants under block plantation and chawki rearing methods

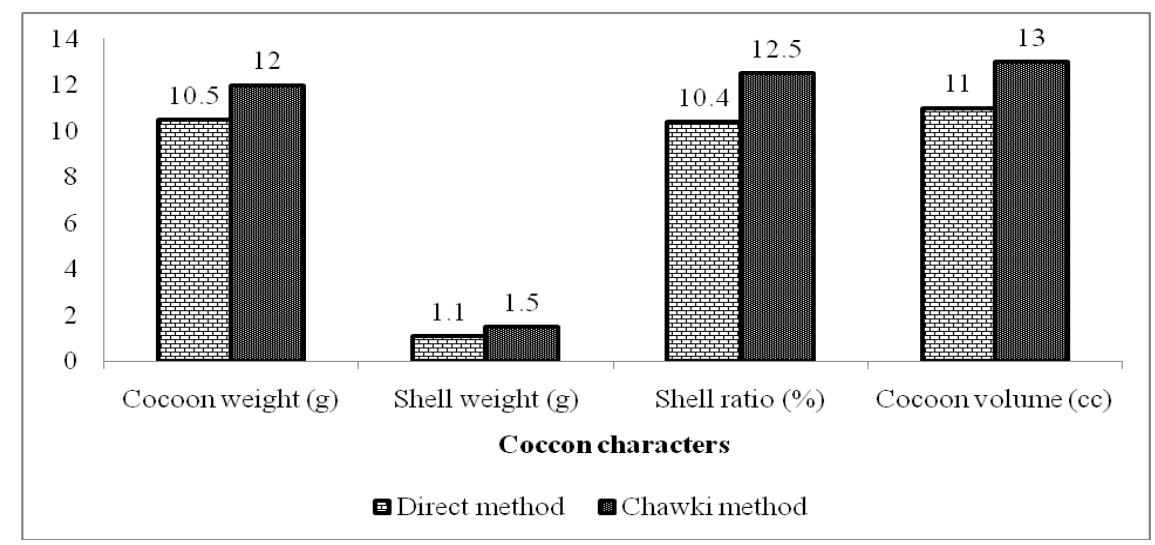

\section{Larval weight}

Data showing in figure 1 illustrated that larval weight under chawki method was observed consistently increasing from I instar stage onwards as compared to direct method silkworm rearing practices i.e., 0.08 and $0.04 \mathrm{~g}$ in chawki and direct method, respectively. The same trend has significantly followed up to fifth instars larval period. It showed that the larvae 
fed with nutritive leaves in chawki garden recorded higher larval weight $(0.08,0.94,7.6$, 13.05 and $41.27 \mathrm{~g}$ during I, II, III, IV and V instars, respectively) as compared to direct method rearing of silkworm $(0.04,0.71,5.1$, 11.08 and $31.0 \mathrm{~g}$ during I, II, III, IV and V instars, respectively). Larvae were fed with health and nutritious leaves of host plants in chawki garden might be possible reason to significant increase in body mass compared to the direct method of silkworm rearing. The healthy supplement feed increase significant in larvae weight (Etebari and Fazilati, 2003). The similar finding was also supported by Mahmoud (2013).

\section{Cocoon characters}

Tasar silkworms reared under chawki garden exerted significant influence on cocoon characters. The average cocoon weight of tasar silkworm in direct and chawki rearing method were 10.5 and $12.0 \mathrm{~g}$, respectively (Fig. 2). Similarly, larvae reared with chawki method were found higher shell weight $(1.5 \mathrm{~g})$ than direct method of rearing. This result showing that all the silkworms fed with chawki leaves observed $36.4 \%$ higher as shell weight as compared to direct method. Whereas, shell ratio percentage was found higher $(12.5 \%)$ under chawki method than direct rearing method. These values are in concurrence with the work of Subburathinum and Krishna (1992) who have supplied with nutrient rich leaves source that favourably influenced higher shell percentage. These above factors are resulted in higher cocoon volume under chawki rearing method $(13 \mathrm{cc})$. The results are in conformity with Rajegowda (2002) who observed higher cocoon and shell weight when silkworm fed nutrient rich hygiene leaves.

In conclusion from above study it is concluded that tasar silkworm reared under chawki garden during first and second instars larvae had less duration of silkworm, higher harvestable cocoons and less mortality rate. Further, silkworm reared under chawki was improved cocoon characters like cocoon weight, silk ratio, silk weight and volume of tasar silk cocoon.

\section{References}

Etebari, K. and M. Fazilati (2003) Effect of feeding on mulberry's supplementary leaves with $\mathrm{N}, \mathrm{P}$, and $\mathrm{K}$ in some biological and biochemical characteristics of silkworm, Journal of Science Technology Agriculture and Natural Resources, 7, 233-244.

Hari Om Agrawal and Seth M. K. (1999) Food plants of the Tasar silkworms, Sericulture in India, Eds. 761-777

Mohanty Prafulla Kumar (2003), Tropical wild silk cocoons of India, Book, Daya Publishing house, New Delhi.

Muhammad Ashfaq, Sajjad Ali, Muhammad Asif and Hanif, (2009) Bioaccumulation of cobalt in silkworm (Bombyx mori L.) in relation to mulberry, soil and wastewater metal concentrations, Process Biochemistry, 44, 1179-1184.

Sekar, K. (1995) Foliar supplementation of soya flour for improving the silk yield of mulberry silkworm, bombyx mori L. M.Sc. Thesis, Tamil Nadu Agricultural University, Coimbatore.

Singh R.N., Bajpayee C.M., Jayaswal J. and Thangavelu (1992) Perspective of biological control in tasar culture, Indian silk, 31(7) 48-50

Subburathinum, K. M. and M. Krishna (1998) Role of Soya bean protein in silkworm nutrition, Indian silk, 9 - 10.

\section{How to cite this article:}

Ramesh Avhad, Navnath sarode, Nayana Khair and Kalyani Dhadage. 2017. Utilization of Mango Peel Powder (MPP) in Mango Nectar Formulation. Int.J.Curr.Microbiol.App.Sci. 6(4): 2421-2425. doi: https://doi.org/10.20546/ijcmas.2017.604.282 